\title{
INSTYTUCJA PRZEDAWNIENIA KARALNOŚCI A DZIALALNOŚĆ POLICYJNYCH ZESPOLÓW DS. PRZESTĘPSTW NIEWYKRYTYCH, TZW. POLICYJNYCH ARCHIWÓW X
}

\begin{abstract}
Streszczenie. Policyjne Zespoły ds. Przestępstw Niewykrytych, zwane potocznie policyjnymi Archiwami X, na stałe wpisały się już w strukturę polskich organów ścigania, stanowiąc istotny element instrumentarium państwa $\mathrm{w}$ walce $\mathrm{z}$ przestępczością. Grupom tym powierzono szczególny rodzaj spraw. Do ich właściwości należą przypadki najcięższych zbrodni (przede wszystkim zabójstw) oraz niewyjaśnionych zdarzeń, popełnionych przed wieloma laty, umorzonych z wynikiem negatywnym - z powodu niewykrycia sprawcy lub braku dostatecznych dowodów jego winy. W niniejszym artykule podjęto próbę ukazania specyfiki spraw podejmowanych przez policyjne Archiwa X. Zwrócono też uwagę na to, jak silnie w pracy tego rodzaju zespołów zaznacza się obecność instytucji przedawnienia karalności przestępstw. Wzgląd na skutki, jakie niesie ze sobą upływ związanych z nią terminów, nie tylko legł u podstaw decyzji o utworzeniu policyjnych Archiwów X, lecz także wywiera wpływ na ich działania w wielu obszarach.
\end{abstract}

Słowa kluczowe: przestępstwa niewykryte, Archiwum X, przedawnienie karalności.

\section{WPROWADZENIE}

Upływ terminu przedawnienia karalności zamyka definitywnie drogę do pociągnięcia sprawcy czynu zabronionego do odpowiedzialności karnej za jego popełnienie. Skutku tego nie zmienia ani ciężar gatunkowy popełnionego przestępstwa, ani wartość zgromadzonego materiału dowodowego. Pomimo relatywnie długich terminów przedawnienia znanych trzem kolejnym kodyfikacjom polskiego prawa karnego, jak również postępu nauki i opartych na jej najnowszych zdobyczach technik i metod wykrywczych, nie każda sprawa znajduje swoje rozwiązanie. Skutki przedawnienia dotyczą zaś każdej kategorii przestępstw pospolitych ${ }^{1}$. Przedawnieniu z mocy prawa (ex lege) ulega zarówno występek kradzieży (na podstawie art. $278 \S 1$ k.k. zagrożonej karą pozbawienia wolności od 3 miesięcy do lat 5), jak i zbrodnia zabójstwa kwalifikowanego szczególnym

* Uniwersytet Łódzki, Wydział Prawa i Administracji, Katedra Postępowania Karnego i Kryminalistyki, aplikant adwokacki, krystian.stanczyk@gmail.com.

${ }^{1}$ Poza zasięgiem przedawnienia pozostają wyłącznie przestępstwa opisane w art. $105 \S 1$ i 2 Kodeksu karnego - ustawy z 6 czerwca 1997 r. 
okrucieństwem sprawcy (na podstawie art. 148 § 2 pkt 1 k.k. zagrożona karą pozbawienia wolności od lat 12, karą 25 lat pozbawienia wolności lub dożywotniego pozbawienia wolności).

W celu ograniczenia skutków przedawnienia i ocalenia od niego choćby spraw najpoważniejszych (o najcięższe przestępstwa, np. zabójstwa, rozboje czy zgwałcenia) koniecznym jest stałe usprawnianie i unowocześnianie metod oraz technik wykrywania przestępstw - dostosowywanie ich do kategorii spraw, którym przychodzi przeciwdziałać. Odpowiedzią państwa na problem spraw wieloletnich stało się więc m.in. powołanie do życia tzw. Policyjnych Zespołów ds. Przestępstw Niewykrytych, będących jednostkami wyspecjalizowanymi i dedykowanymi przypadkom tego właśnie rodzaju. Z uwagi na tak nietypowy przedmiot zainteresowania kwestie przedawnienia karalności odgrywają w pracy tych zespołów szczególnie istotną rolę.

\section{INSTYTUCJA PRZEDAWNIENIA KARALNOŚCI PRZESTĘPSTW W PRZEPISACH PRAWA KARNEGO}

Instytucja przedawnienia, znana w dawnym polskim prawie karnym, znalazła swoje miejsce także w nowoczesnym ustawodawstwie: w tym w tzw. Kodeksie karnym Makarewicza, tj. Kodeksie karnym z dnia 11 lipca 1932 r. (Dz. U. Nr 60, poz. 571 ze zm.) - opisana w rozdziale XIII, w przepisach od art. 86 do art. 89, w Kodeksie karnym z dnia 19 kwietnia 1969 r. (Dz. U. Nr 13, poz. 94 ze zm.) - opisana w rozdziale XIV, w przepisach od art. 105 do art. 109, jak również w obowiązującym od dnia 1 września 1998 r. Kodeksie karnym z dnia 6 czerwca 1997 r. (Dz. U. 2016, poz. 1137 ze zm.) - opisana w rozdziale XI, w przepisach od art. 101 do art. 105.

$\mathrm{Na}$ przestrzeni lat instytucja ta ewoluowała pod wpływem wytycznych zmieniającej się polityki karnej. Najważniejsze modyfikacje odnosiły się do skutków przedawnienia, czynów, których miało ono dotyczyć, a także czynów, które miały być spod przedawnienia wyłączone, długości terminów przedawnienia, chwili, w której rozpoczynał się ich bieg, możliwości jego wstrzymywania, wydłużania itp.

Na dzień 1 lipca 2017 r. Kodeks karny - ustawa z dnia 6 czerwca 1997 r. wyróżnia dwa rodzaje przedawnienia: przedawnienie karalności oraz przedawnienie wykonania kary².

Przedawnienie karalności opisane zostało w art. 101 k.k., zgodnie z którym karalność przestępstwa ustaje, jeżeli od czasu jego popełnienia upłynęło lat:

${ }^{2}$ Tożsame rodzaje przedawnienia - przedawnienie karalności i przedawnienie wykonania kary - przewidywał poprzedni Kodeks karny - ustawa z dnia 19 kwietnia 1969 r. Kodeks karny z 11 lipca 1932 r. wyróżniał natomiast aż trzy rodzaje przedawnienia: przedawnienie ścigania, przedawnienie wyrokowania oraz przedawnienie wykonania kary. 
- 30, gdy czyn stanowi zbrodnię zabójstwa,

- 20, gdy czyn stanowi inną zbrodnię,

- 15, gdy czyn stanowi występek zagrożony karą pozbawienia wolności przekraczającą 5 lat,

- 10, gdy czyn stanowi występek zagrożony karą pozbawienia wolności przekraczającą 3 lata,

-5 , gdy chodzi o pozostałe występki.

Moment rozpoczęcia biegu terminu przedawnienia ustawa określa jako czas popetnienia przestęsstwa, który zgodnie z art. $6 \S 1$ k.k. rozumieć należy jako czas, w którym sprawca działał lub zaniechał działania, do którego był obowiązany. Wyjątek w tym względzie stanowią przestępstwa materialne, wobec których ustawodawca wprowadza rozwiązanie szczególne. W myśl art. $101 \S 3$ k.k., jeżeli dokonanie przestępstwa zależy od nastąpienia określonego w ustawie skutku, bieg przedawnienia rozpoczyna się od czasu, kiedy skutek ten nastąpił (np. bieg terminu przedawnienia karalności zbrodni zabójstwa rozpoczyna się z chwilą śmierci pokrzywdzonego, nie zaś z chwilą, w której sprawca zakończył zadawać ofierze śmiertelne uderzenia) ${ }^{3}$.

Osobną regulację przewidziano dla przestępstw prywatnoskargowych. Zgodnie $\mathrm{z}$ art. $101 \S 2$ k.k. karalność przestępstwa ściganego z oskarżenia prywatnego ustaje z upływem roku od czasu, gdy pokrzywdzony dowiedział się o osobie sprawcy przestępstwa, nie później jednak niż z upływem 3 lat od czasu jego popełnienia.

Przepis art. $101 \S 4$ k.k., w brzmieniu nadanym mu mocą ustawy z dnia 20 lutego 2015 r. o zmianie ustawy - Kodeks karny oraz niektórych innych ustaw (Dz. U. 2015, poz. 396), od dnia 1 lipca 2015 r. stanowi, że w przypadku występków przeciwko życiu i zdrowiu, popełnionych na szkodę małoletniego, zagrożonych karą, której górna granica przekracza 5 lat pozbawienia wolności oraz w przypadku przestępstw określonych w rozdziale XXV (przestępstwa przeciwko wolności seksualnej i obyczajowości), popełnionych na szkodę małoletniego albo, gdy treści pornograficzne obejmują udział małoletniego, wówczas przedawnienie karalności przestępstwa nie może nastąpić przed ukończeniem przez niego 30 roku życia. Regulacja ta stanowi efekt implementacji do polskiego prawa karnego rozwiązań wspólnotowych, zawartych m.in. w treści dyrektywy Parlamentu Europejskiego i Rady nr 2011/93/UE z dnia 13 grudnia 2011 r. w sprawie zwalczania niegodziwego traktowania w celach seksualnych i wykorzystywania

\footnotetext{
${ }^{3}$ Reguła, zgodnie z którą moment ziszczenia się skutku stanowiącego znamię przestępstwa materialnego rozpoczyna bieg terminu przedawnienia karalności ustanowiona została dopiero w Kodeksie karnym - ustawie z dnia 19 kwietnia 1969 r. Poprzedni Kodeks karny - rozporządzenie z dnia 11 lipca 1932 r. - nie przewidywał w tym względzie różnic w odniesieniu do przestępstw materialnych i formalnych. Bieg terminu przedawnienia karalności (wówczas przedawnienia ścigania) rozpoczynał się wówczas - w przypadku obu typów przestępstw - z tą samą chwilą, tj. $\mathrm{z}$ chwilą ich popełnienia.
} 
seksualnego dzieci oraz pornografii dziecięcej, jak również w przepisach konwencji Rady Europy z dnia 25 października 2007 r. o ochronie dzieci przed seksualnym wykorzystaniem i niegodziwym traktowaniem w celach seksualnych - tzw. Konwencja z Lanzarote (Kulik 2016, 63-66).

Uwaga ustawodawcy wielokrotnie koncentrowała się na kwestii dopuszczalności wydłużania podstawowych terminów przedawnienia, w tym także terminów już zainicjowanych (tj. pozostających w biegu). W Kodeksie karnym - ustawie z dnia 6 czerwca 1997 r. rolę taką odgrywa instytucja przerwy biegu terminu przedawnienia karalności, uregulowana w art. 102 k.k. W wyniku nowelizacji dokonanej mocą ustawy z dnia 15 stycznia 2016 r. (Dz. U. 2016, poz. 189), począwszy od dnia 2 marca 2016 r. (tj. od dnia wejścia w życie rzeczonej zmiany), do przerwania biegu terminu przedawnienia karalności dochodzi z chwilą wszczęcia postępowania w sprawie (in rem). Przepis art. 102 k.k. stanowi, że jeżeli w okresie, o którym mowa $\mathrm{w}$ art. 101 (a więc $\mathrm{w}$ okresie biegu podstawowego terminu przedawnienia karalności), wszczęto postępowanie, karalność przestępstw określonych w art. $101 \S 1$ ustaje $\mathrm{z}$ upływem 10 lat, a w pozostałych wypadkach - z upływem 5 lat od zakończenia tego okresu. Odnotować wypada, że w zbliżony sposób instytucja przerwy biegu terminu przedawnienia uregulowana pozostawała w poprzednio obowiązującej ustawie karnej z dnia 19 kwietnia 1969 r. Instytucja ta zastąpiła wówczas instytucję przedawnienia wyrokowania, opisaną w art. 87 Kodeksu karnego z dnia 11 lipca $1932 \mathrm{r}^{4}$ Mimo to, w dalszym ciągu bywa $\mathrm{z}$ nią utożsamiana (Soćko 2012, 197). W nowym Kodeksie karnym - ustawie z dnia 6 czerwca 1997 r. (w jego brzmieniu pierwotnym, obowiązującym na dzień wejścia w życie ustawy, tj. na dzień 1 września 1998 r.) wszczęcie postępowania w sprawie (in rem) nie powodowało już przerwania biegu podstawowych terminów przedawnienia karalności. Efekt taki następował dopiero z chwilą przejścia postępowania karnego $\mathrm{z}$ fazy in rem do fazy in personam, a więc w momencie skierowania postępowania przeciwko domniemanemu sprawcy przestępstwa. Wówczas to podstawowe terminy przedawnienia karalności, opisane w art. 101 k.k., de facto ulegały wydłużeniu. Taki stan rzeczy obowiązywał do nowelizacji z dnia 15 stycznia 2016 r.

W art. 104 § 1 Kodeks karny z 1997 r. przewiduje instytucję spoczywania biegu terminu przedawnienia. Przepis ten stanowi, że przedawnienie nie biegnie, jeżeli przepis ustawy nie pozwala na wszczęcie lub dalsze prowadzenie postępowania karnego (np. z powodu przysługującego sprawcy immunitetu). Nie dotyczy to jednak braku wniosku o ściganie albo oskarżenia prywatnego.

${ }^{4}$ Przepis art. 87 Kodeksu karnego z dnia 11 lipca 1932 r. stanowił, że nie można wydać wyroku skazującego, choćby w tym czasie (tj. w czasie biegu podstawowych terminów przedawnienia ścigania opisanych w art. 86 Kodeksu) przedsięwzięto jakąkolwiek czynność sędziowską w celu ścigania danego sprawcy z powodu danego przestępstwa, jeżeli od popełnienia przestępstwa upłynęło lat: (a) dwadzieścia pięć, jeżeli czyn stanowi zbrodnię, za którą grozi kara śmierci lub dożywotniego więzienia; (b) piętnaście, jeżeli czyn stanowi inną zbrodnię; (c) dziesięć, jeżeli czyn stanowi występek. 
Tragiczne doświadczenia przeszłości, okresu II wojny światowej, a następnie okresu komunizmu, skutkowały decyzją ustawodawcy o wyłączeniu spod przedawnienia tzw. delicta iuris gentium ( $\mathrm{t}$. zbrodni prawa międzynarodowego) w postaci zbrodni przeciwko pokojowi, ludzkości i przestępstw wojennych, jak również umyślnych przestępstw: zabójstwa, ciężkiego uszkodzenia ciała, ciężkiego uszczerbku na zdrowiu lub pozbawienia wolności łączonego ze szczególnym udręczeniem, popełnionych przez funkcjonariuszy publicznych w związku z pełnieniem przez nich obowiązków służbowych (art. 105 § 1 i 2 k.k.).

Przedawnienie wykonania kary opisane zostało natomiast w art. 103 k.k., zgodnie z którym kary nie można wykonać, jeżeli od uprawomocnienia się wyroku skazującego upłynęło lat:

- 30, w razie skazania na karę pozbawienia wolności przekraczającą 5 lat albo karę surowszą,

- 15, w razie skazania na karę pozbawienia wolności nieprzekraczającą 5 lat,

- 10, w razie skazania na inną karę.

Zgodnie z art. $103 \S 2$ k.k. termin dziesięcioletni stosuje się odpowiednio do środków karnych, środków kompensacyjnych oraz przepadku.

Na gruncie przepisów procedury karnej przedawnienie uznaje się zaś za ujemną (negatywną) przesłankę procesową (tzw. przeszkodę procesową) o charakterze bezwzględnym, absolutnym, trwałym, nieusuwalnym. Przepis art. $17 \S 1$ pkt 6 k.p.k. stanowi wyraźnie, że nie wszczyna się postępowania, a wszczęte umarza, gdy nastąpiło przedawnienie karalności. Zdaniem T. Grzegorczyka i J. Tylmana przedawnienie karalności wyklucza możliwość procedowania w sprawie o dany czyn przeciwko określonej osobie w jakimkolwiek układzie procesowym (Grzegorczyk, Tylman 2007, 188-190). W wyroku z dnia 8 czerwca 1977 r. (I KR 87/77, LEX 17010) Sąd Najwyższy, określając przedawnienie mianem bezwzględnej przeszkody procesowej, uznał, że jej stwierdzenie w toku postępowania uniemożliwia wydanie w sprawie zarówno wyroku skazującego, jak i wyroku uniewinniającego. Koniecznym staje się wówczas umorzenie postępowania. W doktrynie tak opisane stanowisko zaakceptował m.in. J. Skorupka (Skorupka 2015, 73). Z czasem jednak Sąd Najwyższy zmodyfikował swój pogląd. W wyroku z dnia 2 lipca 2002 r. (IV KKN 264/99, LEX 54407) Sąd Najwyższy wskazał, że przedawnienie karalności skutkować winno umorzeniem postępowania tylko wtedy, gdy brak jest od razu podstaw do uniewinnienia oskarżonego z braku czynu lub braku znamion czynu jako wykroczenia albo braku winy. Umorzenie z racji przedawnienia wchodziłoby zatem w rachubę zawsze wtedy, gdy kwestie istnienia czynu, jego znamion i odpowiedzialności, wymagają dalszego dowodzenia. Wówczas postępowaniu w tej materii stoi na przeszkodzie przedawnienie karalności.

Z uwagi na swą szczególną łączność z prawem karnym materialnym doktryna uznaje przedawnienie karalności za przesłankę procesową o charakterze stricte materialnym (Sakowicz 2015, 87; Skorupka 2015, 73) bądź o charakterze mieszanym (Grzegorczyk, Tylman 2007, 188-190). 


\section{UZASADNIENIE INSTYTUCJI PRZEDAWNIENIA}

Bez względu na sposób normatywnego ujęcia instytucji przedawnienia, jej sens od początku pozostaje jednakowy - upływ czasu, uznanego przez prawodawcę za właściwy, wyklucza możliwość pociągnięcia sprawcy określonego czynu do odpowiedzialności za jego popełnienie. Innymi słowy, sprawca czynu, który w przewidzianym przez ustawodawcę terminie nie zostaje za czyn swój rozliczony, w rezultacie przedawnienia konsekwencji tych nie ponosi nigdy.

Mimo swej powszechności (instytucja przedawnienia, choć różnorodnie uregulowana, znana jest większości systemów prawa karnego $)^{5}$ uzasadnienie potrzeby istnienia przedawnienia w prawie karnym nie jest tak oczywiste (Soćko 2012, 201). Kwestia ta stanowi zarzewie wciąż żywego doktrynalnego sporu.

Próby wyjaśnienia powodów, dla których za zasadne uznaje się utrzymywanie instytucji przedawnienia w nowoczesnych regulacjach karnych, K. Marszał sklasyfikował w ramach czterech kategorii (rozważania na kanwie zaproponowanej klasyfikacji rozwinął następnie M. Kulik).

Do pierwszej kategorii K. Marszał zaliczył teorie odwołujące się do tzw. racji pozaprawnych, wśród których za dominujący autor uznał argument o łagodzącej sile czasu, leczącej rany i krzywdy wyrządzone przestępstwem, naturalnie przywracającej stan równowagi naruszonej bezprawnym czynem sprawcy, bez ingerencji organów państwa. Do drugiej grupy autor zaliczył teorie oparte na racjach prawno-procesowych. Obok teorii upatrujących uzasadnienia przedawnienia w domniemanej rezygnacji (czy utracie) oskarżyciela z przysługującego mu prawa do wystąpienia ze skargą (aktem oskarżenia), do kategorii tej zaliczono m.in. argumenty dotyczące trudności dowodowych, jakie pojawić się mogą wraz z postępującym zanikaniem śladów przestępstwa. Trzecią kategorię tworzą argumenty prawno-materialne. Wśród nich na uwagę zasługują przede wszystkim te odwołujące się do funkcji prawa karnego i celu, jaki (w zakresie prewencji ogólnej i szczególnej) osiągnąć ma akt pociągnięcia sprawcy czynu zabronionego do odpowiedzialności karnej. Zdaniem zwolenników tego rodzaju argumentacji wymierzenie i wykonanie kary po dłuższym czasie, kiedy ogół społeczeństwa zapomniał już o czynie sprawcy, a sam sprawca uległ zmianie (a nawet odpokutowat zastępczo za swoje winy), staje się niepotrzebne, gdyż nie spełnia celów, jakie postępowanie takie winno realizować. Czwartą, bodajże najliczniejszą, grupę stanowią teorie mieszane, w różnym stopniu odwołujące się do argumentów procesowych, materialnych czy też racji pozaprawnych (Marszał 1972, 50-74; Kulik 2014, 28-61). Próby uzasadnienia instytucji przedawnienia prezentowane $\mathrm{w}$ doktrynie to w zdecydowanej większości teorie mieszane.

Zdaniem J. Makarewicza, jednego ze współautorów Kodeksu karnego z 1932 r., przedawnienie znajduje swe uzasadnienie w upływie czasu, który to

\footnotetext{
${ }^{5}$ Wyjątek stanowi system prawa anglosaskiego.
} 
„przynosi zapomnienie i pobłażliwość”. W upływie czasu autor dostrzegał jednak również ryzyko błędnego rozstrzygnięcia sprawy, a to z powodu postępującej degradacji śladów przestępstwa (np. śmierci świadków, zacierania się w ich pamięci szczegółów zdarzenia). Trudnościom takim kres przynosi instytucja przedawnienia (Makarewicz 1935, 215).

Współtwórca kolejnego, wyrosłego na gruncie nowej sytuacji polityczno-społecznej, socjalistycznego Kodeksu karnego z 1969 r. - I. Andrejew - uzasadnienia instytucji przedawnienia upatrywał przede wszystkim w funkcjach, jakie fakt ukarania sprawcy realizować ma w zakresie prewencji ogólnej i szczególnej. Zdaniem Andrejewa z czasem zanika bowiem w społeczeństwie „wrażenie o przestępstwie". To zaś powoduje, że ukaranie sprawcy staje się zbędne z punktu widzenia społecznego oddziaływania kary (prewencja ogólna). Z czasem ukaranie sprawcy przestaje także realizować cele związane z prewencją indywidualną - zapobiegawczym i wychowawczym oddziaływaniem na sprawcę, zwłaszcza jeśli ten od czasu popełnienia przestępstwa zmienił się i przestrzega obowiązującego porządku prawnego. Poza uzasadnieniem materialno-prawnym autor odwołał się również do argumentów procesowych, wskazując na możliwość wystąpienia z czasem (w sprawach długoletnich) naturalnych trudności dowodowych, a w konsekwencji problemów z ustaleniem okoliczności faktycznych mających stanowić podstawę wyroku (Andrejew 1978, 316).

$\mathrm{W}$ tożsamych argumentach (materialno-prawnych i procesowych) uzasadnienia instytucji przedawnienia doszukują się komentatorzy przepisów nowej ustawy karnej, tj. Kodeksu karnego z 1997 r. - W. Wróbel i A. Zoll. Zdaniem autorów uzasadnienie instytucji przedawnienia wypływa z celów kary. Upływ czasu powoduje bowiem, że odpada możliwość, jak i najczęściej potrzeba, skutecznego oddziaływania na sprawcę czynu zabronionego (prewencja szczególna), a także na społeczeństwo (prewencja ogólna). Z czasem w świadomości społecznej - jak podkreślają autorzy - zatarty zostaje ślad popełnionego przestępstwa. $Z$ upływem czasu zanika też potrzeba zaspokojenia społecznego poczucia sprawiedliwości. Autorzy dodają, że z uwagi na zacieranie się z czasem śladów popełnionego czynu „wzrasta obawa popełnienia błędów w postępowaniu ustalającym podstawy odpowiedzialności karnej” (Wróbel, Zoll 2010, 577-578).

$\mathrm{W}$ argumentach natury materialno-prawnej uzasadnienia przedawnienia poszukuje również M. Kulik. Autor dostrzega je w łagodzącej sile czasu, która rozciągając czasowy związek pomiędzy przestępstwem a karą, powoduje, że pociągnięcie sprawcy do odpowiedzialności karnej staje się niecelowe lub niepotrzebne ze względów ogólnoprewencyjnych i szczególnoprewencyjnych. $\mathrm{W}$ ocenie prawodawcy z czasem zanika więc ,interes państwa w ściganiu sprawcy czynu zabronionego". Interesem tym, zdaniem M. Kulika, jest bowiem realizacja celów z zakresu prewencji generalnej i indywidualnej. Dodatkowo, w opinii autora, istnienie przedawnienia wynikać może także z określonej tradycji (Kulik 2014, 74). 
Dyskusja nad właściwym umotywowaniem potrzeby istnienia instytucji przedawnienia w prawie karnym wykracza poza ramy niniejszego opracowania. Bez wątpienia jednak przywołane koncepcje dowodzą jej wielowymiarowości oraz złożoności upatrywanych w niej celów. W świetle prezentowanych teorii przedawnienie zrywa więc związek między przestępstwem a karą, kłaść ma kres brakowi aktywności oskarżyciela, ma zabezpieczać przed wydaniem wyroku niesłusznego, opartego na wątpliwej jakości środkach dowodowych, uniemożliwiać wymierzenie kary niesprawiedliwej z punktu widzenia ogółu społeczeństwa, które o czynie sprawcy zdążyło już zapomnieć, ma wykluczać wymierzenie kary nazbyt surowej względem sprawcy, który od czasu przestępstwa zmienił się, nawiązał nowe stosunki społeczne i przedłużającym się stanem niepewności, co do swego losu (oczekiwaniem na karę) niejako odpokutowat zastępczo za swoje winy. Przedawnienie zapobiega rozdrapywaniu starych ran, stanowi wyraz zasady humanitaryzmu, zapobiega wtórnej wiktymizacji pokrzywdzonego itp. (Kulik 2014, 28-61).

Poza wspomnianymi rolami, jakie doktryna prawa karnego upatruje w przedawnieniu, w instytucji tej dostrzega się niekiedy także i funkcję, którą najtrafniej określić wypada mianem „funkcji motywacyjnej”. W opinii S. Zimmermanna, którego stanowisko przytacza w swym opracowaniu M. Kulik, ,istnienie przedawnienia zabezpiecza przed bezczynnością organów procesowych, mobilizując je do sprawnego działania" (Kulik 2014, 38). Wobec dyrektyw legalizmu (art. 10 $\S 2$ k.p.k.) czy szybkości postępowania (art. 2 § 1 pkt 4 k.p.k.), obowiązujących organy ścigania i wymiaru sprawiedliwości, a przy tym świadomość nieodwracalności skutków, jakie niesie ze sobą upływ terminów przedawnienia, jej istnienie stanowić musi czynnik stymulujący i wymuszajacy na organach procesowych podejmowanie działań niezbędnych do efektywnego rozpoznania i rozstrzygnięcia sprawy, nim możliwość taka ustanie bezpowrotnie. Brak nakazanej prawem aktywności organów procesowych rodzić może ich odpowiedzialność na podstawie art. 231 k.k. ${ }^{6}$

Ogólnodostępna statystyka policyjna pozwala zaobserwować, że w 2016 r. ogólnopolski wskaźnik wykrywalności przestępstw wyniósł 66,5\%, a w sprawach najpoważniejszych, w tym o zabójstwa czy zgwałcenia, odpowiednio 96,3\% i 80,5\% (dane statystyczne Komendy Głównej Policji) ${ }^{7}$. Każdego roku przybywa

${ }^{6}$ Zgodnie $\mathrm{z}$ art. 231 § 1 k.k. funkcjonariusz publiczny, który, przekraczając swoje uprawnienia lub nie dopełniając obowiązków, działa na szkodę interesu publicznego lub prywatnego, podlega karze pozbawienia wolności do lat 3 .

${ }^{7}$ Dane statystyczne Komendy Głównej Policji dostępne na stronie internetowej: http://www. policja.pl. Dane zawarte w raportach dotyczących: (1) ogólnej liczby przestępstw stwierdzonych, wykrytych oraz wskaźnika ich wykrywalności: http://statystyka.policja.pl/st/przestepstwa-ogolem/121940,Przestepstwa-ogolem.html; (2) liczby zabójstw stwierdzonych, wykrytych oraz wskaźnika ich wykrywalności: http://statystyka.policja.pl/st/przestepstwa-ogolem/przestepstwa-kryminalne/zabojstwo/64003,Zabojstwo.html oraz (3) liczby zgwałceń stwierdzonych, wykrytych 
zatem spraw nierozwiązanych, postępowań umorzonych z powodu niewykrycia sprawcy czy też braku dostatecznych dowodów jego winy. W części z nich zdarza się, że czynności wykrywcze, kontynuowane pomimo umorzenia postępowania (często także czynności podejmowane do innych spraw), dostarczają finalnie podstaw do podjęcia bądź wznowienia zakończonych postępowań, a także sformułowania i wystąpienia do sądu z aktem oskarżenia. W pozostałych przypadkach termin przedawnienia dobiega końca, a akta spraw, po upływie terminów archiwizacji, ulegają zbrakowaniu.

Wspomniana wcześniej funkcja motywacyjna, przypisywana instytucji przedawnienia przez S. Zimmermanna (Kulik 2014, 38), nakazuje organom ścigania wracać do spraw w przeszłości nierozwiązanych - podejmować kolejne próby ich wyjaśnienia i wykrycia sprawcy. Za efekt funkcji motywacyjnej postrzegać można m.in. decyzję o powołaniu do życia policyjnych Archiwów X.

\section{POLICYJNE ZESPOLY DS. PRZESTĘPSTW NIEWYKRYTYCH - TZW. POLICYJNE ARCHIWA $X$}

Decyzja o powołaniu w strukturach Komendy Wojewódzkiej Policji w Krakowie w styczniu 2004 r. pierwszego w Polsce Zespołu ds. Przestępstw Niewykrytych miała charakter precedensowy i brzemienny w skutkach (Litka, Michalec, Nowak 2016, 9) ${ }^{8}$. Sukcesy grupy, określonej wkrótce przez prasę mianem tzw. policyjnego Archiwum X, zapoczątkowały bowiem proces formowania podobnych zespołów w innych jednostkach wojewódzkich, dając w ten sposób szansę na to, aby wiele spośród spraw dotąd nierozwiązanych znalazło wreszcie swój finał w sentencjach wyroków skazujących. Przypomnieć wypada, że do zadań policyjnych Zespołów ds. Przestępstw Niewykrytych należy przede wszystkim analiza spraw starych, dotyczących zdarzeń często z bardzo odległej przeszłości. W taki sposób zakres obowiązków przypisywanych policyjnym Archiwom X zdefiniowano m.in. w decyzji Komendanta Wojewódzkiego Policji w Katowicach (nr 211/05 z 2.06.2005 r.). Wśród zadań scedowanych na śląskie Archiwum wymieniono „analizę niewykrytych spraw z lat ubiegłych dotyczących przestępstw przeciwko życiu i zdrowiu oraz zaginięć osób [...], ocenę postępowań przygotowawczych

oraz wskaźnika ich wykrywalności: http://statystyka. policja.pl/st/przestepstwa-ogolem/przestępstwa-kryminalne/zgwalcenie/122293,Zgwalcenie.html (dostęp 1.07.2017).

${ }^{8}$ Krakowski Zespół ds. Przestępstw Niewykrytych o nazwie: Grupa Operacyjno-Śledcza KWP w Krakowie do spraw niewykrytych zabójstw o nazwie Archiwum X powstał formalnie w styczniu 2004 r., choć w rzeczywistości początki tego zespołu sięgają 1999 r. Do zadań grupy należy „wskazywanie i wykrywanie [tzw.] ciemnej liczby zabójstw”. W obszarze zainteresowania zespołu pozostają zatem: „zgony uznane za zaginięcia, utonięcia, samobójstwa lub nieszczęśliwe wypadki, sprawy odłożone na półkę w policyjnym archiwum z adnotacją: niewykrycie sprawcy, czy po prostu z niewłaściwą kwalifikacją czynu" (Litka, Michalec, Nowak 2016, 9). 
oraz rozpracowań operacyjnych pod kątem ewentualnych sprawców i ich typowania, modus operandi, zabezpieczonych śladów, miejsca dokonania przestępstwa itd. [...]”. W sposób zbliżony zakres obowiązków powierzonych zespołom, funkcjonującym w ramach pozostałych Komend Wojewódzkich Policji w Polsce, normują decyzje właściwych im Komendantów Wojewódzkich Policji.

Sukcesy policyjnych Zespołów ds. Przestępstw Niewykrytych to przypadki ciężkich zbrodni (przede wszystkim zabójstw, rozbojów itp.), w których, pomimo upływu lat udaje się wreszcie ustalić sprawcę przestępstwa i pociągnąc go do odpowiedzialności karnej. To także sprawy uznawane dotąd za niewyjaśnione, zaginięcia, zdarzenia wadliwie zakwalifikowane (jako przypadki nieumyślnego spowodowania śmierci, zdarzenia losowe, samobójstwa), których rzeczywisty charakter okazał się jednak zgoła odmienny od pierwotnie zakładanych wersji śledczych. Powtórna ocena zgromadzonego w sprawach tych materiału dowodowego, dokonana przez wyspecjalizowanych w tego rodzaju przypadkach funkcjonariuszy i ekspertów - czasami przy wykorzystaniu najnowocześniejszych zdobyczy nauki, innowacyjnych technik i metod kryminalistycznych, innym razem w efekcie wyłącznie świeżego spojrzenia na materiał dowodowy i okoliczności przypadku - pozwala na wyjaśnienie spraw przez lata uchodzących za niemożliwe do rozwiązania.

O efektach pracy poszczególnych Archiwów społeczeństwo dowiaduje się przede wszystkim za pośrednictwem środków masowego przekazu. Nietuzinkowość spraw tego rodzaju wzbudza uzasadnione zainteresowanie społeczne. Dla przykładu, w 2011 r. łódzkie media poinformowały o zatrzymaniu sprawców brutalnego zabójstwa połączonego z rozkawałkowaniem zwłok ofiary, ujętych po niemal 11 latach od popełnionej zbrodni (KSAF 2011, 6). W 2015 r. funkcjonariusze bydgoskiego Archiwum X zatrzymali i doprowadzili do osądzenia oraz skazania sprawcę zabójstwa 22-letniej Joanny S., zamordowanej przed ponad 20 laty, w 1994 r. (Rymaszewska 2015). W 2016 r. media przypomniały również o zabójstwie 70-letniej gdańszczanki. Sprawcę tej zbrodni zatrzymano dopiero po niemal 29 latach od śmierci ofiary (WS/GP 2016).

Wypada zauważyć, że aktywność policyjnych Archiwów X oraz rzetelne informowanie społeczeństwa o pozytywnych wynikach pracy tych zespołów nie mogą pozostawać bez wpływu na proces urzeczywistniania celów i realizowania funkcji prawa karnego, w tym zwłaszcza funkcji prewencyjnej czy sprawiedliwościowej.

Pozytywne wyniki pracy funkcjonariuszy i ekspertów policyjnych Archiwów X dowodzą zdolności organów ścigania do wykrywania sprawców przestępstw popełnionych przed wieloma laty. Skuteczność aparatu ścigania, duży stopień wykrywalności sprawców popełnionych przestępstw, w tym i tych dotąd nierozwiązanych (obok stabilności całego systemu prawa karnego), pozwalają na właściwe kształtowanie prawnej świadomości społeczeństwa (prewencja ogólna pozytywna), dając wyraz prawidłowości funkcjonowania państwa i stanowionego przez nie prawa 
(Warylewski 2015, 69-70). Co więcej, sprawność działania organów ścigania oraz wymiaru sprawiedliwości, a także przekonanie o nieuchronności wykrycia i poniesienia kary za popełnione przestępstwo, oddziaływać mogą hamująco (odstraszająco) na potencjalnych sprawców podobnych czynów. Świadomość konsekwencji - niechybnych i koniecznych, nawet po wielu latach od popełnienia przestępstwa - realizować może skutecznie postulaty wynikające z zadań prewencji generalnej negatywnej.

Działalność policyjnych Archiwów X pozwala także na realizację funkcji sprawiedliwościowej. Wykrycie sprawcy przestępstwa, a przede wszystkim zdolność do dowiedzenia mu winy za popełnioną zbrodnię, daje szansę na wymierzenie sprawcy kary, bądź środka, współmiernych do wagi i stopnia społecznej szkodliwości czynu. Zaryzykować można ocenę, że w wielu przypadkach już sam fakt skutecznego pociągnięcia sprawcy dawnej zbrodni do zasłużonej odpowiedzialności karnej czyni choć w części zadość społecznemu poczuciu sprawiedliwości. W ocenie J. Warylewskiego społeczne poczucie sprawiedliwości zaspokaja bowiem nie tylko surowa kara, lecz także ,kara nieuchronna, szybka i wdrożona do wykonania" (Warylewski 2015, 70). Prawidłowa realizacja przez prawo karne funkcji sprawiedliwościowej - jak piszą zaś W. Wróbel i A. Zoll - wzmacnia w odczuciu społecznym przekonanie, że zło jest piętnowane, a jego sprawca doznaje zasłużonej dolegliwości. Sprawca swoim atakiem na dobro prawne wyrządza bowiem zło i państwo jest zobowiązane na ten fakt zareagować - adekwatnie do popełnionego czynu (Wróbel, Zoll 2010, 43). Trafnie bowiem zauważa J. Warylewski, że dla społeczeństwa nie do zaakceptowania byłaby sytuacja, w której sprawca przestępstwa pozostałby bezkarny (Warylewski 2015, 70).

\section{WPLYW INSTYTUCJI PRZEDAWNIENIA KARALNOŚCI PRZESTĘPSTW NA PRACĘ POLICYJNYCH ARCHIWÓW X}

Tak scharakteryzowana działalność policyjnych Archiwów X pozwala dostrzegać w nich swoiste remedium na przedawnialność przestępstw najpoważniejszych. Poza przypadkami wymienionymi w art. $105 \S 1-\S 2$ k.k. (tj. przestępstw prawa międzynarodowego oraz wskazanych w nim przestępstw popełnionych przez funkcjonariuszy publicznych) ustawodawca nie wyłącza bowiem spod przedawnienia jakiejkolwiek kategorii przestępstw pospolitych (np. kwalifikowanych postaci zbrodni zabójstwa). Działalność policyjnych Archiwów w wielu przypadkach stanowi zatem ostatnią szansę na ponowne zweryfikowanie zebranych w sprawach tych dowodów i podjęcie (bądź wznowienie) umorzonych postępowań przed definitywnym ustaniem ich karalności.

Z uwagi na szczególny obszar aktywności Policyjnych Zespołów ds. Przestępstw Niewykrytych przedawnienie stanowi element stale obecny w pracy Archiwów X. Nie oznacza to bynajmniej, że instytucja ta pozostaje bez znaczenia 
dla innych organów procesowych. Treść przywołanego wcześniej art. 17 § 1 pkt 6 k.p.k. nie pozostawia w tym aspekcie żadnych wątpliwości. Niemniej jednak można zaryzykować tezę, że w sprawach nowych, podejmowanych bezpośrednio po popełnieniu przestępstwa, a więc bezpośrednio po rozpoczęciu biegu terminów przedawnienia, skutki, jakie niesie ze sobą ich upływ, jawić się mogą prowadzącym śledztwa jako bardzo odległe, a wręcz abstrakcyjne. W konsekwencji wzgląd na przedawnienie nie determinuje $\mathrm{w}$ tak znaczący sposób działań i podejmowanych w sprawie decyzji. Co się zaś tyczy spraw pozostających w obszarze zainteresowania policyjnych Archiwów X - skutki przedawnienia bywają w nich wręcz namacalne. W sprawach należących do właściwości Zespołów ds. Przestępstw Niewykrytych bieg terminu przedawnienia karalności został już bowiem dawno zainicjowany. Przypomnieć należy, że zgodnie z art. 101 § 1 i 3 Kodeksu karnego z 1997 r. bieg terminu przedawnienia karalności rozpoczyna się z chwilą popełnienia przestępstwa. W przypadku dokonanych przestępstw materialnych bieg ten, zgodnie z art. $101 \S 3$ k.k., rozpoczyna się, gdy nastąpił skutek (np. z chwilą śmierci ofiary zabójstwa). Tożsame reguły dotyczące początku biegu terminu przedawnienia karalności przewidywał poprzedni Kodeks karny - ustawa z dnia 19 kwietnia 1969 r. (por. art. $105 \S 1$ i $\S 3$ d.k.k.). Z chwilą umorzenia postępowania, np. z powodu niewykrycia sprawcy, termin przedawnienia karalności nie spoczywa, lecz biegnie dalej. Co za tym idzie, w chwili, w której przypadek taki trafia do policyjnego Archiwum X termin pozostały do końca okresu jego karalności przeważnie różni się znacząco od terminów przedawnienia przewidzianych w ustawie. Zazwyczaj bywa bowiem zdecydowanie krótszy. Zdarzają się też sprawy „na granicy przedawnienia”. Dla przykładu, z danych udostępnionych przez Komendę Wojewódzką Policji w Katowicach ${ }^{9}$ wynika, że sprawy o zabójstwa badane przez śląski Zespół ds. Przestępstw Niewykrytych zakończone wynikiem pozytywnym, tj. wnioskiem o skierowanie do sądu aktu oskarżenia, dotyczyły czynów popełnionych w latach 1989-1994. Przypadki badane przez zespoły z innych Komend Wojewódzkich Policji bywają jeszcze starsze. Taka specyfika powierzonych spraw pociąga za sobą doniosłe konsekwencje i doskonale ilustrujące wpływ instytucji przedawnienia karalności na codzienną aktywność policyjnych Archiwów X.

Sprawy badane przez policyjne Archiwa X to w zdecydowanej większości przypadki przez zespoły te wyselekcjonowane. Przedawnienie karalności wyznacza zatem temporalne granice obszaru, w obrębie którego Archiwa poszukują spraw do dalszych badań. Przypomnieć należy, że podstawową rolę w pracy policyjnych Archiwów X odgrywa art. 327 k.p.k. pozwalający na podjęcie lub wznowienie postępowań umorzonych, jak również dokonywanie czynności dowodowych poprzedzających taką decyzję. Zgodnie więc z art. 327 § 1 k.p.k. „Umorzone postępowanie przygotowawcze może być w każdym czasie podjęte

\footnotetext{
${ }^{9}$ Dane przekazane przy piśmie z dnia 14.03.2016 r. - L.dz. KD 5614-2/984/16/GM.
} 
na nowo na mocy postanowienia prokuratora [...]”. Jeśli zaś postępowanie to toczyć się ma przeciwko osobie, wobec której toczyło się uprzednio (wobec osoby, której przysługiwał już status osoby podejrzanej), wówczas stosownie do art. 327 $\S 2$ k.p.k. „Prawomocnie umorzone postępowanie przygotowawcze wznawia się [...] na mocy postanowienia prokuratora nadrzędnego nad tym, który wydał lub zatwierdził postanowienie o umorzeniu, pod warunkiem jednak, że ujawnią się nowe istotne fakty lub dowody nie znane w poprzednim postępowaniu [...]". Przed wydaniem postanowienia o podjęciu lub wznowieniu postępowania, na podstawie art. $327 \S 3$ k.p.k., prokurator może przedsięwziąć osobiście lub zlecić policji, dokonanie niezbędnych czynności dowodowych w celu sprawdzenia okoliczności uzasadniających wydanie postanowienia. Przepisy ustawy nie pozwalają jednak na podejmowanie ani wznawianie spraw o przestępstwa, których termin przedawnienia karalności zdążył już upłynąć ${ }^{10}$, bez względu na to, czy zgromadzony w nich materiał dowodowy decyzję taką uzasadnia, a sprawca jest zdolny do wzięcia udziału w procesie i odbycia ewentualnie orzeczonej kary. Upływ terminów przedawnienia definitywnie wygasza możliwość pociągnięcia sprawcy do odpowiedzialności karnej za popełnione przestępstwo. Sprawy, w których termin przedawnienia upłynął, pozostają zatem poza zakresem zainteresowania policyjnych Archiwów X.

Prawidłowe oznaczenie daty, w której termin przedawnienia karalności rozpoczyna swój bieg oraz chwili, w której karalność przestępstwa definitywnie ustaje, w pracy policyjnych Archiwów X nabiera zatem znaczenia fundamentalnego. Z uwagi na skrócone okresy karalności, jakie stają się udziałem spraw badanych przez policyjne Zespoły ds. Przestępstw Niewykrytych, ewentualny błąd, pozornie nieistotna (np. kilkudniowa) omyłka rachunkowa, niedokładność czynionych ustaleń, powodować mogą skutki nieodwracalne. W konsekwencji tego rodzaju uchybień dojść może do pozostawienia poza obszarem zainteresowania zespołu spraw, których termin przedawnienia karalności jeszcze nie upłynął. W rezultacie Archiwum odstąpić może od analizy przypadku, w którym zgromadzony materiał dowodowy rokuje wykrycie sprawcy i jego osądzenie, bezzasadnie przyjmując, że karalność tego przestępstwa zdążyła już wygasnąć. Błędów takich nie da się naprawić.

Wskazać wypada, że trudności w prawidłowym oznaczeniu terminu przedawnienia - jego początku i kresu - wynikać mogą z wadliwie dokonanych ustaleń faktycznych (np. nieprecyzyjnie oznaczonej chwili śmierci ofiary zabójstwa - por. art. $101 \S 3$ k.k.), jak również z błędnie zrekonstruowanego stanu prawnego. Uzasadnionych wątpliwości przysporzyć mogą m.in. przepisy intertemporalne (tzw. przepisy międzyczasowe), mocą których ustawodawca określa

${ }^{10}$ Dla porządku przypomnieć w tym miejscu należy, że przedawnienie karalności nie wyklucza możliwości wniesienia i rozpoznania kasacji (por. art. 529 k.p.k.), jak również wznowienia postępowania (por. art. $545 \S 1$ k.p.k.) - na korzyść oskarżonego. 
wzajemny stosunek pomiędzy przepisami dotychczasowymi a zmieniającymi je przepisami ustaw nowelizacyjnych. Przykład tego rodzaju regulacji stanowić może art. 15 przepisów wprowadzających aktualnie obowiązujący Kodeks karny - ustawę z dnia 6 czerwca 1997 r. (Dz. U. Nr 88, poz. 554 ze zm., dalej p.w.k.k.). W przepisie tym ustawodawca zdecydował, że do czynów popełnionych przed wejściem w życie Kodeksu karnego z 1997 r. stosować należy przepisy tego Kodeksu o przedawnieniu i zatarciu skazania, chyba że termin przedawnienia już upłynął. Nowa zasada stanowi zatem lex specialis wobec ugruntowanej dotychczas reguły wyrażonej w art. 2 § 1 Kodeksu karnego z 1969 r. oraz w art. 4 § 1 Kodeksu karnego z 1997 r. ${ }^{11}$ (por. post. SN z dnia 19 sierpnia 1999 r., I KZP 25/99, Legalis nr 44496). Moc nowej zasady ustanowionej art. 15 p.w.k.k. ograniczona została jednak wyłącznie do kwestii w niej uregulowanych, tj. przedawnienia oraz zatarcia skazania. Konsekwencje nowej regulacji wyjaśnił Sąd Najwyższy, wskazując wprost, że jeżeli przed dniem wejścia w życie nowego Kodeksu karnego - ustawy z dnia 6 czerwca 1997 r. „,na podstawie dotychczasowych przepisów, to jest art. 105 i 106 [Kodeksu z 1969 r.] nie nastąpiło przedawnienie, kwestię przedawnienia karalności ocenia się według art. 101 i 102 [Kodeksu z 1997 r.], niezależnie od tego, czy do oceny prawnej konkretnego zachowania stosuje się - z uwagi na treść art. 4 § 1 k.k. - przepisy Kodeksu karnego z 1969 r. jako ustawy względniejszej, czy też nie" (por. post. SN z dnia 5 maja 2005 r., V KK 63/05, Legalis nr 97655). Reguła ta stanowi ,wyłom w zasadzie stosowania tylko jednej ustawy dla oceny konsekwencji prawnokarnych czynu" (I KZP 25/99). Przepis ten był także przedmiotem oceny Trybunału Konstytucyjnego, co do jego zgodności z treścią art. 2 oraz art. 42 ust. 1 ustawy zasadniczej i wywodzoną z nich zasadą lex retro non agit (por. wyrok TK z dnia 25 maja 2004 r., SK 44/03, Legalis nr 62902). W praktyce owa precedensowa regulacja doprowadziła do wydłużenia zainicjowanych już terminów przedawnienia karalności niektórych przestępstw popełnionych pod rządami poprzedniego Kodeksu karnego - ustawy z dnia 19 kwietnia 1969 r. Dotyczyło to m.in. zbrodni zabójstwa w jej typie podstawowym, spenalizowanym $w$ art. $148 \S 1$ d.k.k. Na gruncie przepisów poprzedniej ustawy karnej termin przedawnienia karalności zbrodni zabójstwa wynosił bowiem 20 lat (art. $105 \S 1$ pkt 1 d.k.k.) ${ }^{12}$. Nowy Kodeks przypisał jej termin dłuż-

${ }^{11}$ Przepis art. 4 § 1 Kodeksu karnego - ustawy z dnia 6 czerwca 1997 r. stanowi, że jeżeli w czasie orzekania obowiązuje ustawa inna niż w czasie popełnienia przestępstwa, stosuje się ustawę nową, jednakże należy stosować ustawę obowiązującą poprzednio, jeżeli jest względniejsza dla sprawcy.

${ }_{12}$ Dla porządku przypomnieć w tym miejscu należy, że ustawą z dnia 12 lipca $1995 \mathrm{r}$. (Dz. U. Nr 95, poz. 475) zmieniony został art. $105 \S 1$ pkt 1 d.k.k. w ten sposób, że 20-letni termin przedawnienia karalności zastąpiony został terminem 30-letnim. Ustawa nowelizacyjna opublikowana została w dniu 19 sierpnia 1995 r. Zmiany weszły w życie w dniu 20 listopada 1995 r. Jednakże z powodu braku przepisu międzyczasowego nowa regulacja podlegać musiała ogólnej regule kolizyjnej z art. $2 \S 1$ d.k.k. Jako że dokonana zmiana pogarszała w rzeczywistości sytuację prawną 
szy, 30-letni (art. $101 \S 1$ pkt 1 k.k.). Jeśli zatem ów krótszy termin przedawnienia karalności, określony w przepisach Kodeksu karnego z 1969 r., nie zdążył upłynąć do dnia wejścia w życie nowej kodyfikacji (tj. do dnia 1 września 1998 r.), w jego miejsce wstępował termin dłuższy, określony w art. 101 Kodeksu karnego z 1997 r. Regulacja ta stanowiła przedmiot licznych orzeczeń Sądu Najwyższego, rozstrzygających wątpliwości stron oraz naprawiających uchybienia sądów meriti (np. wyrok SN z dnia 8 lutego 2006 r., III KK 265/05, Legalis nr 75500; wyrok SN z dnia 4 stycznia 2007 r., V KK 264/06, Legalis nr 122131). Błędy organów procesowych bądź to ignorujących zupełnie fakt istnienia rzeczonego przepisu intertemporalnego, bądź też w sposób nieuprawniony nadających w tym względzie prymat regule kolizyjnej, opisanej w przywołanym wcześniej art. 4 § 1 k.k., prowadziły do nieuzasadnionego umarzania postępowań karnych na podstawie art. $17 \S 1$ pkt 6 k.p.k., mimo że w rzeczywistości termin przedawnienia karalności, określony przepisami nowej kodyfikacji, nie zdążył w nich upłynąć. W rezultacie tych uchybień za definitywnie zakończone uznawano sprawy, których karalność jeszcze nie ustała.

Problemy dotyczące właściwej interpretacji przepisów międzyczasowych nie ograniczają się jedynie do prawidłowego stosowania kodyfikacji z 1969 r. i 1997 r. Tożsame problemy towarzyszyć mogą każdej kolejnej nowelizacji. Trafnie bowiem skonstatował Sąd Najwyższy, że działanie art. 15 p.w.k.k. ma charakter wyłącznie jednorazowy. Sąd Najwyższy wyjaśnił, że przepis ten nie będzie mieć zastosowania w tych przypadkach, w których do nowelizacji przepisów kodeksu karnego z 1997 r. o przedawnieniu doszłoby ewentualnie po dniu 1 września 1998 r. Wówczas to zastosowanie znajduje, bowiem ogólna reguła kolizyjna określona w art. 4 § 1 k.k., chyba że ustawodawca postanowi inaczej, umieszczając w ustawie zmieniającej właściwy przepis międzyczasowy (I KZP 25/99). Analiza przepisów dotychczasowych ustaw nowelizacyjnych pozwala dostrzec brak konsekwencji polskiego ustawodawcy w sposobie regulowania kwestii wpływu zmian legislacyjnych na bieg zainicjowanych już terminów przedawnienia karalności. Zdarza się bowiem, że ustawodawca umieszcza w ustawie nowelizującej przepis stanowiący dokładny odpowiednik art. 15 p.w.k.k. - np. art. 2 ustawy o zmianie ustawy - Kodeks karny z dnia 3 czerwca 2005 r. (Dz. U. Nr 132, poz. 1109). Bywa jednak i tak, że ustawodawca przepisów intertemporalnych nie wprowadza w ogóle, oddając tym samym kwestie przedawnienia pod osąd art. 4 $\S 1$ k.k., m.in. w przypadku ustawy o zmianie ustawy - Kodeks karny oraz niektórych innych ustaw z dnia 24 października 2008 r. (Dz. U. Nr 214, poz. 1344). W tym stanie rzeczy proces rekonstrukcji stanu prawnego, w oparciu o który dokonuje się następnie określenia chwili przedawnienia karalności przestępstwa, wymaga rzetelnej analizy zmian legislacyjnych, jakie miały miejsce w okresie

oskarżonego - wydłużała bowiem okres karalności przestępstwa - jej zastosowanie dotyczyć mogło czynów popełnionych dopiero od dnia jej wejścia w życie, tj. od dnia 20 listopada 1995 r. 
biegu tego terminu. Wielość nowelizacji, ich różnorodność czy też precedensowy charakter wprowadzanych regulacji prowadzić mogą do błędów, te zaś do niepowetowanych skutków.

Nie ulega także wątpliwości, że przedawnialność przestępstw stanowić powinna istotny czynnik wpływający na sposób organizacji pracy Archiwów, w tym także sposób planowania koniecznych do przeprowadzenia czynności dowodowych, wybór właściwych i najefektywniejszych środków i metod potrzebnych do wyjaśnienia sprawy w możliwie najkrótszym terminie. Przedłużające się działania zespołu, będące wynikiem braku właściwej organizacji pracy, nieprawidłowego jej rozplanowania, wykonywania czynności dowodowo zbędnych, odbierać mogą czas potrzebny na rzetelne przeprowadzenie procesu we wszystkich jego stadiach - przygotowawczym i jurysdykcyjnym. Specyfika spraw podejmowanych przez policyjne Archiwa X, w tym przede wszystkim ich krótkie okresy karalności, czynią koniecznym wypracowanie przez poszczególne zespoły właściwych im, skutecznych metod postępowania w tego rodzaju przypadkach.

Nie sposób także nie zauważyć, że pozytywne wyniki pracy Policyjnych Zespołów ds. Przestępstw Niewykrytych, dotyczące coraz większej liczby przypadków i spraw z coraz to odleglejszej przeszłości, dają asumpt do dyskusji nad zasadnością obecnego status quo. Przykłady rozwiązanych po latach spraw wzmacniają pytanie o trafność aktualnego kształtu instytucji przedawnienia, w tym adekwatność określonych przez ustawodawcę terminów przedawnienia karalności, braku wyłączeń w odniesieniu np. do najcięższych przestępstw, takich jak kwalifikowane typy zbrodni zabójstwa (por. np. Bojarski 2012, 221). Wątpliwości tego rodzaju wzmagać może dostrzegalna tendencja ustawodawcy do wydłużania okresów karalności przestępstw - czy to w drodze bezpośredniej ingerencji w podstawowe terminy przedawnienia karalności, czy też poprzez redefiniowanie instytucji przerwy jego biegu. Argumentów w tej dyskusji dostarczać może również dominujący w doktrynie i orzecznictwie pogląd na charakter prawny przedawnienia. W okresie obowiązywania poprzedniego Kodeksu karnego - ustawy z dnia 19 kwietnia 1969 r. - pod rządami której popełniane były przestępstwa, stanowiące dziś przedmiot analizy policyjnych Archiwów X, I. Andrejew pisał już, że ,przedawnienie nie jest prawem przestępcy nabywanym w chwili popełnienia przestępstwa i to takim, że ustawodawca nie może go zmienić. Jeżeli w chwili popełnienia przestępstwa obowiązuje jakiś okres przedawnienia, to w czasie trwania tego okresu ustawodawca może go przedłużyć albo wstrzymać bieg przedawnienia" (Andrejew 1978, 318). Rozważania w przedmiocie charakteru prawnego instytucji przedawnienia karalności czynił także Trybunał Konstytucyjny (SK 44/03). W uzasadnieniu swego stanowiska - dotyczącego zgodności art. 15 p.w.k.k. z art. 2 i art. 42 ust. 1 Konstytucji RP - Trybunał wyjaśnił, że choć instytucja przedawnienia stanowi element porządku prawa karnego, to traktowana być może jedynie jako element pewnej polityki karnej. Obywatel nie może zaś oczekiwać korzyści, które dla niego mogłyby wynikać z takiej, a nie innej 
polityki karnej, bo ta - w zależności od istoty zagrożeń związanych z konkretnymi przestępstwami - może podlegać modyfikacjom i zmianom. Trybunał odniósł się również do poglądów upatrujących w przedawnieniu konstytucyjnie chronionego prawa obywatela. Sąd konstytucyjny orzekł wprost, że przedawnienia prawa takiego nie stanowi. Trybunał wyjaśnił, że Konstytucja RP nie przewiduje zasady stanowiącej, że karalność przestępstw i wykonanie kary ulegają przedawnieniu. Zasady tej nie można również wyprowadzić z klauzuli demokratycznego państwa prawnego (por. art. 2 Konstytucji RP) ani też z art. 42 ust. 1 Konstytucji RP. Zasada taka nie wynika również $\mathrm{z}$ art. $43^{13} \mathrm{i}$ art. $44^{14}$ ustawy zasadniczej. Trybunał uznał bowiem, że choć w przepisach tych mowa o instytucji przedawnienia, to jednak $\mathrm{w}$ zupełnie odmiennym (niż $\mathrm{w}$ aspekcie konstytucyjnego prawa podmiotowego jednostki) kontekście. Zdaniem sędziów Trybunału treść art. 43 i 44 Konstytucji RP, choć dotyczy przedawnienia, nie pozwala przyjąć, że istnieje konstytucyjne ,prawo do przedawnienia” czy choćby ekspektatywa takiego prawa.

W rezultacie przyjętego stanowiska Trybunał skonstatował, że skoro „przedawnienie nie jest podmiotowym prawem konstytucyjnym [to] teoretycznie, gdyby ustawodawca nie przewidział tej instytucji, nie można byłoby twierdzić, że jakieś konstytucyjne prawa i wolności obywatelskie zostały w ten sposób naruszone”. Tożsamy pogląd wyrazili m.in. A. Zoll i W. Wróbel, uznając, że „skoro przedawnienie jest wyrazem prowadzenia określonej polityki karnej i nie jest związane z prawami podmiotowymi sprawcy przestępstwa, [to] ustawodawca ma względną swobodę kształtowania terminów przedawnienia, a także rezygnacji w ogóle z przedawnienia karalności określonych przestępstw" (Wróbel, Zoll 2010, 582).

\section{PODSUMOWANIE}

Reasumując, z uwagi na specyficzny charakter spraw, jakie zdecydowano się powierzyć właściwości policyjnych Archiwów X, instytucja przedawnienia karalności szczególnie silnie zaznacza swą obecność w pracy tych zespołów.

Przede wszystkim wskazać wypada, że przedawnialność przestępstw oraz doniosłość skutków, jakie niesie ze sobą upływ jej terminów, stanowią jedną z przyczyn, dla których Archiwa utworzono. Podstawowy cel Policyjnych Zespołów ds. Przestępstw Niewykrytych stanowi bowiem wyjaśnianie spraw zakończonych $\mathrm{w}$ przeszłości umorzeniem postępowania z powodu niewykrycia sprawcy

${ }^{13}$ Przepis art. 43 Konstytucji RP stanowi, że zbrodnie wojenne i zbrodnie przeciwko ludzkości nie podlegają przedawnieniu.

${ }^{14}$ Przepis art. 44 Konstytucji RP stanowi, że bieg przedawnienia w stosunku do przestępstw, nieściganych z przyczyn politycznych, popełnionych przez funkcjonariuszy publicznych lub na ich zlecenie, ulega zawieszeniu do czasu ustania tych przyczyn. 
lub braku dostatecznych dowodów jego winy, zanim możliwość pociągnięcia sprawcy do odpowiedzialności karnej definitywnie ustanie.

Scedowanie na Archiwa obowiązku samodzielnego poszukiwania i selekcji przypadków rokujących możliwość wyjaśnienia pociąga za sobą konieczność właściwej oceny okresów ich karalności. Wymaga to skrupulatnej analizy zgromadzonego w sprawie materiału dowodowego (w celu ustalenia okoliczności wyznaczających początek biegu terminu przedawnienia, np. chwili śmierci ofiary zabójstwa - por. art. $101 \S 4$ k.k.), jak również rzetelnej rekonstrukcji stanu prawnego determinującego bieg terminu przedawnienia i chwilę jego zakończenia. Kształt instytucji przedawnienia wyznacza de facto obszar działalności policyjnych Archiwów X.

Nadto terminy pozostałe do końca okresów karalności przestępstw badanych przez Policyjne Zespoły ds. Przestępstw Niewykrytych - zazwyczaj zdecydowanie krótsze od terminów opisanych w ustawie - determinują sposób analizy przypadków, wymuszając na Archiwach konieczność wypracowania metod najefektywniejszych, często rodzących potrzebę wykorzystywania najnowocześniejszych zdobyczy nauki, metod i technik kryminalistycznych. Co również istotne, doświadczeni funkcjonariusze i eksperci winni kierować się przy tym nie tylko potrzebą wyjaśnienia sprawy, lecz także koniecznością jej skutecznego osądzenia. Istotne staje się zatem wygospodarowanie odpowiedniej nadwyżki czasu niezbędnego do przeprowadzenia postępowania karnego w pełnym zakresie.

Sukcesy Policyjnych Zespołów ds. Przestępstw Niewykrytych stwarzają wreszcie pretekst do dyskusji nad adekwatnością obecnego status quo. Nie kwestionując bynajmniej zasadności instytucji przedawnienia jako takiej, wskazać jednak należy, że obserwowana zdolność organów ścigania do rozwiązywania spraw po latach i pociągania sprawców, często bardzo poważnych przestępstw, do odpowiedzialności karnej za ich popełnienie, nakłada na doktrynę obowiązek przekonującego uargumentowania potrzeby istnienia instytucji przedawnienia karalności w prawie karnym w jej obecnym kształcie.

\section{BIBLIOGRAFIA}

Andrejew, Igor. 1978. Polskie prawo karne w zarysie, Warszawa: Państwowe Wydawnictwo Naukowe. Bojarski, Tadeusz. 2012. „Komentarz do rozdziału XI”. W Tadeusz Bojarski, Aneta Michalska-Warias, Joanna Piórkowska-Flieger, Maciej Szwarczyk. Kodeks Karny. Komentarz. Red. Tadeusz Bojarski. Warszawa: LexisNexis.

Grzegorczyk, Tomasz, Janusz Tylman. 2007. Polskie postepowanie karne. Warszawa: LexisNexis. KSAF. 2011. „Mordercy wpadli po 11 latach”. Magazyn Express Ilustrowany 4.

Kulik, Marek. 2014. Przedawnienie karalności i przedawnienie wykonania kary w polskim prawie karnym. Warszawa: C.H. Beck.

Kulik, Marek. 2016. „Zmiany przepisów dotyczących przedawnienia wprowadzone ustawą z dnia 20 lutego 2015 r. o zmianie ustawy - Kodeks karny oraz niektórych innych ustaw". Annales Universitatis Mariae Curie-Skłodowska Lublin - Polonia LXIII, 1: 61-79.

Litka, Piotr, Bogdan Michalec, Mariusz Nowak. 2016. Polskie Archiwum X. Kraków: Wydawnictwo WAM. 
Makarewicz, Juliusz. 1935. Kodeks karny z komentarzem. Lwów: Wydawnictwo Zakładu Narodowego im. Ossolińskich.

Marszał, Kazimierz. 1972. Przedawnienie w prawie karnym. Warszawa: Państwowe Wydawnictwo Naukowe.

Rymaszewska, Krystyna. 2015. Po 20 latach odpowie za morderstwo Joanny Sendeckiej. Portal internetowy TVP3 Bydgoszcz, 23.07.2015. http://bydgoszcz.tvp.p1/20956345/po-20-latachodpowie-za-morderstwo-joanny-sendeckiej [dostęp 1.07.2017].

Sakowicz, Andrzej. 2015. „Komentarz do art. 17 k.p.k.”. W Andrzej Sakowicz, Katarzyna Boratyńska, Adam Górski, Michał Królikowski, Marcin Warchoł, Andrzej Ważny. Kodeks postępowania karnego. Komentarz, Red. Andrzej Sakowicz. Warszawa: C.H. Beck.

Skorupka, Jerzy. 2015. „Komentarz do art. 17 k.p.k.”, W Kodeks postępowania karnego. Komentarz. Red. Jerzy Skorupka. Warszawa: C.H. Beck.

Soćko, Michał. 2012. „Istota i kryminalnopolityczne znaczenie przedawnienia w prawie karnym”. Studia Iuridica Lublinensia 17: 193-212.

Warylewski, Jarosław. 2015. Prawo karne. Część ogólna. Warszawa: Wolters Kluwer.

Wróbel, Włodzimierz, Andrzej Zoll. 2010. Polskie prawo karne. Część ogólna. Kraków: Wydawnictwo Znak.

WS/GP. 2016. Rozwiąali zagadke brutalnego morderstwa kobiety sprzed 29 lat. Portal internetowy TVN24, 24.05.2016. http://www.tvn24.pl/pomorze,42/gdansk-rozwiazali-zagadke-morderstwa-sprzed-29-lat,646469.html [dostęp 1.07.2017].

\title{
Strony internetowe
}

http://statystyka.policja.pl/st/przestepstwa-ogolem/121940,Przestepstwa-ogolem.html [dostęp 1.07.2017].

http://statystyka.policja.pl/st/przestepstwa-ogolem/przestepstwa-kryminalne/zabojstwo/64003, Zabojstwo.html [dostęp 1.07.2017].

http://statystyka.policja.pl/st/przestepstwa-ogolem/przestępstwa-kryminalne/zgwalcenie/122293, Zgwalcenie. html [dostęp 1.07.2017].

http://www.policja.pl [dostęp 1.07.2017].

\section{Krystian M. Stańczyk}

\section{TIME LIMITATION OF PUNISHABILITY AND ACTIVITY OF POLICE TEAMS DEALING WITH UNDETECTED CRIME - THE POLICE X ARCHIVES}

\begin{abstract}
The Police Teams dealing with undetected crime, commonly known the Police $\mathrm{X}$ Archives have long been a part of the structure of Polish law enforcement agencies being an important element of the State's instruments in the fight against crime. These groups were entrusted with a particular type of cases which cover cases of the most severe crimes (primarily murders) and unexplained events, committed many years ago, ended with negative results due to an undetected perpetrator or lack of sufficient evidence of their guilt. This article attempts to illustrate the specificities of the Police X Archives. It has also been pointed out how strong the presence of the institution of the time limitation of punishability is in work of such a team. Considering the effects of the time limits associated with it, it not only has led to the decision to create the Police X Archives, but it also influences their actions in many areas.
\end{abstract}

Keywords: undetected offences, Police X Archives, time limitation of punishability. 